\title{
ANALYZING THE STATUS OF WOMEN IN E-GOVERNANCE ERA OF BANGLADESH: CHALLENGES AND POTENTIALS
}

\author{
Tasnuva Habib Zisan \\ Assistant Professor \\ Department of Public Administration \\ University of Barishal, Bangladesh \\ E-mail: th_zisan@yahoo.com
}

\begin{abstract}
This study examines the present status of women in the context of Electronic governance initiatives in Bangladesh. As a developing country, Bangladesh is stepping toward achieving E-governance where there is always a debate of the digital divide. Hence, this study tries to explore the challenges faced by women for access to and control over resources specifically the Information and Communication Technology tools or devices. It also aims to unveil the potentials of women's access and usage of such resources. This study employs survey data collected from study areas. Both urban and rural areas are chosen to get an overall scenario of women's status. This study is conducted in an inductive approach and findings are analyzed in a qualitative approach. The result shows that the status of women in access and usage of ICT varies in urban and rural areas due to some common constraints. The major findings of the study suggest that Information and Communication Technology has some potential for women empowerment which is explained as a case study. In this era of E-governance, most women are still facing gendered challenges such as lack of control over resources, awareness, education, and cybersecurity.
\end{abstract}

Keywords: Digital, E-Governance, Information and Communication Technology, Tools, Bangladesh, Woman.

JEL Classification Codes: H41, J70, O33, O38.

\section{INTRODUCTION}

The recently emerged concept of E-Governance is now one of the basic trends of the modern world. Bangladesh with some initiatives taken already as well as other developing countries is rapidly stepping towards achieving E-governance. Electronic Governance popularly known as E-governance means the application of information and communication technology (ICT) for delivering government services, exchange of information, communication and transactions, integration of various standalone systems and services between government-to-customer(G2C), government-to-business $(\mathrm{G} 2 \mathrm{~B})$, government-to-government $(\mathrm{G} 2 \mathrm{G})$ as well as back-office processes and interactions within the entire government framework (Ndou, 2004; Taifur, 2006). E-governance is a whole process where the government cannot progress without the customer's involvement. Hence, existing challenges must be addressed for special women.

In recent years, to promote E-Governance, Government has taken several initiatives. The development of ICTs and Digitalization is one of the initiatives. Information and Communication technology refers to the application of computing technology to process information particularly the use of electronic and computer software to convert, store, protect, process, and retrieve information from anywhere at any time. From the available literature, it is obvious that ICT has huge potentials for all people. Yet some literature shows that constraints like the digital divide and gendered usage of 
ICT tools are also growing in this era. In this study, the status of women in ICT usage is a core concern. Analyzing women's access to and control over ICT tools leads to the overall status of women at all levels of society. Access to and use of ICT, in general, is linked to social and economic factors. Development in such factors can have an overall positive impact on women's work and livelihood. Such as, women have successfully used ICTs for their interests by forming peer networks through employment-interest groups such as the Self-Employed Women Association (SEWA) in India, the umbrella of micro-credit activities like the Grameen Village Phone Program in Bangladesh. Therefore, women's empowerment can be enhanced if the focus is given on the gaps and addressed sensitively. For this, it is necessary to find out constraints. To identify the constraints and potentials for access, usage, and control of ICT by women and the impact of different infrastructure in both urban and rural areas of Bangladesh, three different local level areas (Manda, Dhaka, Barisal Sadar, Barisal, and Char Sholakia, Kishoregonj) have been taken as study areas.

\section{Research Objectives}

The main objective of this study is to find out the levels of women's usage of ICT and the factors that influence women's access in the era of E-governance in Bangladesh. This study tries to find out the constraints of woman's access to ICT in both rural and urban areas and explore the potentials.

\section{Research Questions}

- What are the determinant factors behind the digital divide?

- What are the constraints faced by women?

\section{LITERATURE REVIEW AND GAP ANALYSIS}

The major objective of the study was to identify the potentials of supporting women in ICT. It is identified that E-governance has huge potentiality if it is utilized productively. In the five-stage model of e-governance, there are five stages of e-government development in a country-a) Webpresence, b) Interaction, c) Transaction, d) Transformation, e) E-democracy. In light of this model, this study shows that if we want to achieve e-democracy in a true sense, women must be supported for better involvement in ICT.

A study recommends that the availability of technology plays a key role in social inclusion. Positive experiences from other countries and within the country can be explored in the process of Egovernance. On the other hand, it says that we need to be alert to the reality that ICTs can reinforce gender differences or can help to overcome them (Tandon et al., 2012).

In the available literature, it is found that e-governance may accelerate women's empowerment, but there is no specific study found on the productive usage of ICT tools so that women's access and control over resources can be ensured. In recent years, the availability of ICT tools has been increased rapidly but this availability has only brought a quantitative change in scenario, lack of access and control over these tools are still constraints for supporting women in productive usage.

\section{METHODOLOGY}

This study is conducted with an inductive approach. The study is based on primary data. For data collection unified questionnaire was prepared and a structured observation method was also used for depth investigation of the attitudes of the respondents. A purposive sampling method was used to choose the respondents as women from different categories were to be included. For analyzing collected data qualitative approach is used.

The rationales behind selecting the study areas are-

- Bangladesh has several geographical divisions which have specific differences. Manda, Char sholakia, and Barisal Sadar are in different geographical locations respectively at the 
capital city, Middle part of the country, and southern part of Bengal. Hence, these represent the real scenario all over the country. The study areas represent the urban-rural and local levels of Bangladesh. The availability of ICT tools and other indicators are different in these areas. Hence, it is rational to choose these areas to identify the level of supporting women in ICTs.

- The socio-cultural environment and administrative structure are also different. For this research one union (Manda), one Upazila (Barisal Sadar), and one village (Char Sholakia) have been chosen, so that impact of infrastructural variations can be identified. The data were collected between 2016 to 2018 from the given study areas.

- The study areas are different from the percentage of female, high educational and awareness problems. As the objectives of the study are to find out the ways to encourage women in using ICTs both in rural and urban areas, variations of areas will present area-specific constraints for women's access to ICT. All the respondents are women.

\section{RESEARCH FINDINGS}

The impact of women's access to ICT and constraints faced is analyzed below with some indicators. These are ICT policy, Socioeconomic and cultural factors, Digital literacy, Availability of ICT tools, Formal education, Women entrepreneurs related to ICTs \& Digital security.

\section{ICT Policy}

In recent years, some initiatives like the ICT act and policy measures have been taken but these are not concerned about the constraints faced. Without a strong supportive policy framework, the digital divide cannot be addressed. Women's access to ICT remains an after-thought. Bangladesh's National Information and Communication Technology (ICT) Policy has outlined some measures for the introduction of ICT education in public and private universities, teachers' training in ICTs, deployment of virtual ICT teachers, and web-based course work. There is no mention of specific measures to address the gendered barriers. Some of the following policy initiatives are indicated through the respondent's opinion. In a study, it is identified that public spaces are highly uncomfortable to be used by rural women. This is because cultural and social restrictions act as a glass ceiling on women. Most of the women avoid such public spaces. Union Digital center is the most effective initiative in rural areas.

The following table shows the percentage of access to such ICT initiatives:

Table 1. Women access to ICT

\begin{tabular}{|l|l|l|l|l|l|l|l|l|}
\hline \multirow{2}{*}{ Access to ICT } & \multicolumn{2}{|l|}{ Barisal Sadar } & \multicolumn{2}{l|}{ South Manda } & \multicolumn{2}{l|}{ Char Sholakia } & \multicolumn{2}{l|}{ Total } \\
\cline { 2 - 9 } & No. & $\%$ & No. & $\%$ & No. & $\%$ & No. & $\%$ (Average) \\
\hline $\begin{array}{l}\text { Aware of and use } \\
\text { cyber kiosk and UDC }\end{array}$ & 60 & 60 & 35 & 70 & 28 & 56 & 123 & 62 \\
\hline $\begin{array}{l}\text { Not aware about } \\
\text { recent policy initiatives }\end{array}$ & 25 & 25 & 06 & 12 & 14 & 28 & 45 & 21.66 \\
\hline $\begin{array}{l}\text { Don't have any } \\
\text { interest }\end{array}$ & 15 & 15 & 09 & 18 & 08 & 16 & 32 & 16.34 \\
\hline Total & 100 & 100 & 50 & 100 & 50 & 10 & 200 & 100 \\
\hline
\end{tabular}

Source: Data collected from study areas and prepared by the author 
Among 100 respondents of Barisal Sadar, $60 \%$ of women are aware of recent policy initiatives, while $25 \%$ of women are not familiar with the cyber kiosk and Union Digital center. Most of the respondents think that policy initiatives like- cyber kiosks at the post office; Union Digital center, etc. are supportive to women. This scenario presents that initiatives encourage women's access to ICT. At South Manda, 70\% of respondents are aware of Cyber kiosks in post offices and UDCs. But $12 \%$ of women do not know about and use these privileges. Respondents think that if women are aware of these initiatives, they will avail themselves of those. At Char Sholakia, 56\% of respondents know ICT policy. On the other hand, $28 \%$ of women do not know about the initiatives. The overall scenario is that $62 \%$ of respondents are aware of the necessity of gender supportive policy, $21.66 \%$ are not aware of these services and $16.34 \%$ have no interest in such privileges. Many women are aware of the initiative, but they don't like to go there. Male dominance in such public places resists women.

\section{Socio-Economic and Cultural Factors}

A male group of the society can avail the web access facility from commercial centers or outside the home, but the local women community of Bangladesh has limited access due to some social and cultural environment. Unfortunately, due to family obligations and service, they can't spare sufficient time for using the net (Akbar, 2018). On the other hand, the economic condition of the people is one of the vital issues for computer use and internet connectivity. Generally, on average wealthy and educated as well as young, urban, and male have internet access, which appears that economic solvency and education are the major factors during internet diffusion. Most of which are not favorable in Bangladesh (Akbar, 2018).

The following table shows mentioned social, cultural, and economic factors by the respondents:

Table 2. Social factors of respondents

\begin{tabular}{|l|l|l|l|l|l|l|l|l|}
\hline \multirow{2}{*}{ Access to ICTs } & \multicolumn{2}{l}{ Baisal Sadar } & \multicolumn{2}{l|}{ South Manda } & \multicolumn{2}{l|}{ Char Sholakia } & \multicolumn{2}{l|}{ Total } \\
\cline { 2 - 10 } & No. & $\%$ & No. & $\%$ & No. & $\%$ & No. & $\%$ \\
\hline Time and cost & 20 & 20 & 6 & 12 & 7 & 14 & 33 & 15.34 \\
\hline Family responsibility & 46 & 46 & 16 & 32 & 32 & 64 & 94 & 47.34 \\
\hline Awareness & 12 & 12 & 5 & 10 & 4 & 8 & 21 & 10 \\
\hline Public Space & 6 & 6 & 11 & 22 & 3 & 6 & 20 & 11.33 \\
\hline Complexity & 6 & 6 & 8 & 16 & 2 & 4 & 16 & 8.66 \\
\hline Environment & 10 & 10 & 4 & 8 & 2 & 4 & 16 & 7.33 \\
\hline Total & 100 & 100 & 50 & 100 & 50 & 100 & 200 & 100 \\
\hline
\end{tabular}

Source: Data collected from respondents in study areas

At Barisal Sadar, $46 \%$ claim family responsibility is the major socio-economic and cultural factor affecting access to ICT. At South Manda 32\% of women and at Char Sholakia, 64\% of women think family responsibility is the most influential factor. Among 200 respondents $15.34 \%$ opines that ICT tools are time and cost consuming, $10 \%$ says that they are not familiar with the usage of ICTs, $11.33 \%$ avoid public spaces, $8.66 \%$ assumes ICT tools as complicated, and $7.33 \%$ of women think that there is no proper environment of access and usage. Both in urban and rural areas social and cultural taboos result in a lack of control over devices. 


\section{Digital Literacy}

According to Md. Shahid Uddin Akbar, CEO, womenBD.com, Bangladesh is facing an acute crisis of skilled computer users due to literacy problems. Information in the net is designed in advanced technology, which requires adequate knowledge for the user. Digital literacy has been not so familiar to women, especially rural women. In this context, various respondents like- housewives, students, job holders, and other professionals were interviewed. Most of the respondents think that digital literacy is very necessary for a regular user of ICT tools.

Among 100 respondents of Barisal Sadar, 35 were housewives, 35 students, 15 job holders related to ICT, and 15 others (illiterate/ unemployed/single, etc.) were interviewed. Lack of digital literacy creates dependency upon other members of the family for access to devices. Respondents opined that updated knowledge of ICT tools is hard to reach as they have no time other than household work.

Among 50 respondents 15 were housewives, 10 jobholders, 10 students, and 15 experts at South Manda. Whereas, at Char Sholakia, 19 housewives, 5 jobholders, 20 students, and 6 experts were interviewed. Respondents who are working outside have some digital literacy, but others only use these devices for communication. Digital literacy is not familiar to most housewives whereas students mostly use ICT tools for entertainment.

\section{Availability of ICT Tools}

Availability of ICT tools is the main factor behind women's less access. Though it is a major obstacle to using the internet for all in Bangladesh, it is worse in the context of women's usage. The internet and telecommunication network are still an urban privilege as this is more concentrated in urban areas. Mobile operators are providing substantial service in and outside urban areas using 3G/ EDGE WiMAX. However, recently Bangladesh has seen phenomenal growth in Internet usage due to government initiatives are known as the a2i (2011) project have impacted the growth of users.

Available ICT tools encourage women's use and control. The following table shows the level of availability in the study areas. The relation between access to ICT and the availability of ICT tools has been identified. In study areas, there is a difference in infrastructure. At Barisal Sadar, South Manda, and Char sholakia respondents were asked to select the level of availability of ICT tools. The respondents chose the level according to their area and how often they use these tools. In a study on the Barisal district, it was found that only $13 \%$ area is covered by $3 \mathrm{G}$ networks (Zisan, 2014). The comparative scenario is presented below:

Table 3. Status of availability of ICT tools

\begin{tabular}{|l|l|l|l|l|l|l|l|l|}
\hline \multirow{2}{*}{ Access to ICT } & \multicolumn{2}{|l|}{ Barisal Sadar } & \multicolumn{2}{l|}{ South Manda } & \multicolumn{2}{l|}{ Char Sholakia } & \multicolumn{2}{l|}{ Total } \\
\cline { 2 - 9 } & No. & $\%$ & No. & $\%$ & No. & $\%$ & No. & $\%$ \\
\hline $\begin{array}{l}\text { Modern \& } \\
\text { Available ICT } \\
\text { tools }\end{array}$ & 59 & 59 & 19 & 38 & 14 & 28 & 92 & 41.67 \\
\hline $\begin{array}{l}\text { Moderately } \\
\text { available }\end{array}$ & 31 & 31 & 21 & 42 & 29 & 58 & 81 & 43.67 \\
\hline $\begin{array}{l}\text { Limited and not } \\
\text { continuous }\end{array}$ & 10 & 10 & 7 & 14 & 6 & 12 & 23 & 12 \\
\hline Not available & 0 & 0 & 3 & 6 & 1 & 2 & 4 & 2.66 \\
\hline Total & 100 & 100 & 50 & 100 & 50 & 100 & 200 & 100 \\
\hline
\end{tabular}

Source: Collected and prepared by the author 
Among respondents of urban areas (Manda and Barisal Sadar), respectively 59\% and 38\% opines that ICT tools in these areas are modern and available enough. Another $28 \%$ in the rural area (Char Sholakia) says that ICT tools are available. On average, $12 \%$ of respondents do not find ICT tools continuous and limited. $2.66 \%$ of respondents say that such tools are not available. Availability of such tools affects accesses to ICT tools. From the above table, it is clear that ICT tools are comparatively more available and modern in urban areas (Barisal Sadar and South Manda). But most of the respondents expressed that the frequency is not good at all in rural areas. According to ICT experts, practitioners, trainers, and entrepreneurs, availability is the first priority for supporting women in ICTs.

Table 4. Formal education and access to ICT

\begin{tabular}{|l|l|l|l|l|l|l|l|l|}
\hline Access to & \multicolumn{2}{l}{ Barisal Sadar } & \multicolumn{2}{l}{ South Manda } & \multicolumn{2}{l}{ Char Sholakia } & \multicolumn{2}{l|}{ Total } \\
\hline ICT & No. & $\%$ & No. & $\%$ & No. & $\%$ & No. & $\%$ \\
\hline Illiterate & 1 & 1 & 2 & 4 & 2 & 4 & 5 & 3 \\
\hline Literate & 7 & 7 & 5 & 10 & 4 & 8 & 16 & 8.34 \\
\hline $\begin{array}{l}\text { Primary } \\
\text { education }\end{array}$ & 7 & 7 & 10 & 20 & 5 & 10 & 22 & 12.33 \\
\hline SSC & 23 & 23 & 15 & 30 & 12 & 24 & 50 & 25.66 \\
\hline HSC & 25 & 25 & 8 & 16 & 10 & 20 & 43 & 20.33 \\
\hline Graduate & 15 & 15 & 5 & 10 & 10 & 20 & 30 & 15 \\
\hline Masters & 20 & 20 & 5 & 10 & 5 & 10 & 30 & 13.33 \\
\hline $\begin{array}{l}\text { Technical } \\
\text { education }\end{array}$ & 2 & 2 & 0 & 0 & 0 & 0 & 2 & 0.67 \\
\hline Others & 0 & 0 & 0 & 0 & 2 & 4 & 2 & 1.34 \\
\hline Total & 100 & 100 & 50 & 100 & 50 & 100 & 200 & 100 \\
\hline
\end{tabular}

Source: Prepared by the author based on collected data

The percentage of respondents in the level of Secondary education (SSC) is $23 \%$ at Barisal Sadar, 30\% at Manda, and 24\% at Char Sholakia. The highest percentage is of SSC 30\% at Manda. A little number has technical education. The respondents opined that education influences the usage of ICT tools. Among total respondents 3\% are illiterate and $8.34 \%$ are literate. Another $12.33 \%$ have gone through primary education. It is noted that the rate of illiteracy is more in rural areas and the higher education rate is more in urban areas. Education encourages women's access to ICTs.

Other education includes self-education, vocational training, etc. In the study, two respondents have been categorized as others who received vocational training. The above data shows that level of education is higher in urban areas than in rural areas. According to respondents, educated women can use ICT tools and control.

\section{Women Entrepreneurs \& ICT Usage}

The use of ICT and digital devices are already proved to be an obvious instrument for entrepreneurs. Women entrepreneurs can overcome common barriers and be successful in business. Along with telecommunication networks and digitalized information networks rural women are also involving in online businesses. Many telecommunication companies offer ICT devices and tools for women entrepreneurs. By building a network among businesses, women will be able to share experiences and 
gain better access into the booming ICT sector, receive ICT training and be prepared to benefit from such initiatives. To find out the influence of access to ICT on entrepreneurship, in this study it is identified that through entrepreneurship economic empowerment can be achieved. Moreover, respondents advocated that through the use of ICT they can receive foreign remittance easily, create self-employment and get ICT training. Some respondents opined that involvement with the business, communication skills, involvement in ICT-related jobs, etc. are influenced by the usage of ICT.

Table 5. Women entrepreneurs \& ICTs

\begin{tabular}{|c|c|c|c|c|c|c|c|c|}
\hline \multirow[t]{2}{*}{ Access to ICT } & \multicolumn{2}{|c|}{ Barisal Sadar } & \multicolumn{2}{|c|}{ South Manda } & \multicolumn{2}{|c|}{$\begin{array}{l}\text { Char } \\
\text { Sholakia }\end{array}$} & \multicolumn{2}{|c|}{ Total } \\
\hline & No. & $\%$ & No. & $\%$ & No. & $\%$ & No. & $\%$ \\
\hline Economic Empowerment & 7 & 7 & 3 & 6 & 4 & 8 & 14 & 7 \\
\hline The beneficiary of Foreign & 28 & 28 & 14 & 28 & 13 & 26 & 55 & 27.33 \\
\hline Employment & 33 & 33 & 10 & 20 & 10 & 20 & 53 & 24.33 \\
\hline ICT training & 10 & 10 & 5 & 10 & 3 & 6 & 18 & 8.66 \\
\hline Involvement with business & 12 & 12 & 8 & 16 & 10 & 20 & 30 & 16 \\
\hline Communication Skill & 5 & 5 & 5 & 10 & 5 & 10 & 15 & 8.34 \\
\hline $\begin{array}{l}\text { Involvement in } \\
\text { ICT Sector }\end{array}$ & 5 & 5 & 5 & 10 & 5 & 10 & 15 & 8.34 \\
\hline Total & 100 & 100 & 50 & 100 & 50 & 100 & 200 & 100 \\
\hline
\end{tabular}

Source: Data collected from the study area and prepared by the author

Respondents were asked if they think that access to ICT is linked to women's empowerment and entrepreneurship. The above table shows that $7 \%$ of respondents think that economic empowerment influences access to ICT. Among respondents, 27.34\% opines that foreign remittance influences women's access to ICT. Employment and involvement with jobs is a factor for access to ICT- said $24.34 \%$ of respondents. In both urban and rural areas, $8.67 \%$ of respondents expressed that training related to ICT can enhance access to ICT. Women entrepreneurs, according to $16 \%$ women cause more access to ICT for their business activities. The percentage is higher in rural areas. Another $8.34 \%$ of respondents advocate that communication skills and entry to the ICT sector encourage access to ICT.

\section{Digital Security}

Most of the developing countries like Bangladesh have limitations of access to information and available access is not affordable because of the inadequacy of existing infrastructure. The challenges are posed by the lack of an integrated computer security system and education about computer security. There is a need for collaboration, cooperation, and investment for security (Salim, 2005). In the following table, the relation between digital security and access to ICT has been shown. According to $22 \%$ of women of Manda, cybersecurity is a factor behind access to ICT. On average $18 \%$ of respondents are familiar with cybersecurity. On the other hand, $8 \%$ of women have not even listened to it. 
Table 6. Digital security and access to ICT

\begin{tabular}{|l|l|l|l|l|l|l|l|l|}
\hline \multirow{2}{*}{ Access to ICT } & \multicolumn{2}{|l|}{ Barisal Sadar } & \multicolumn{2}{l|}{ South Manda } & \multicolumn{2}{l|}{ Char Sholakia } & \multicolumn{2}{l|}{ Total } \\
\cline { 2 - 9 } & No. & $\%$ & No. & \% & No. & $\%$ & No. & $\%$ \\
\hline Cybersecurity & 22 & 22 & 10 & 20 & 6 & 12 & 38 & 18 \\
\hline Fear of hacking & 29 & 29 & 14 & 28 & 9 & 18 & 52 & 25 \\
\hline $\begin{array}{l}\text { Misuse of ICT } \\
\text { tools }\end{array}$ & 39 & 39 & 20 & 40 & 30 & 60 & 89 & 46.34 \\
\hline $\begin{array}{l}\text { Lack of legal } \\
\text { support }\end{array}$ & 12 & 12 & 4 & 8 & 9 & 18 & 25 & 12.67 \\
\hline Not aware & 8 & 8 & 2 & 4 & 6 & 12 & 16 & 8 \\
\hline Total & 100 & 100 & 50 & 100 & 50 & 100 & 200 & 100 \\
\hline
\end{tabular}

Source: Prepared by the author

Misuse of ICT tools has been the highest $(60 \%)$ concern even in rural areas. Lack of legal support on various offenses is also affecting access to ICT by women. On the other hand, $46.34 \%$ of respondents think that misuse of ICT tools affects the appropriate usage of ICTs. Another $12.67 \%$ of women opine that there is a lack of women-friendly law and legal support.

Among 200 respondents $29 \%$ of respondents of Barisal Sadar says that fear of hacking websites, e-mails, and social networks are also influential factors. Whereas, $28 \%$ of respondents at South Manda express in the same way and $18 \%$ of respondents at Char Sholakia also consider this as a part of digital security concern. In this study, respondents were asked to mention cybersecurity factors like- cybercrime, fear of hacking, misuse of ICT tools, lack of legal support, etc. Some of the respondents $(8 \%)$ are not even aware of cybersecurity.

Though there are security threats, ICT has potentialities for women's empowerment. One of the respondents mentioned that the usage of ICT has made her life easier.

Mst. Sabina Yasmin, Age-32 years, a working woman, advocates that the multifaceted use of mobile has made her life more comfortable. She has to maintain her family responsibilities like- paying electricity bills, bringing goods for daily consumption, and also her job. According to Yasmin-all these would be difficult if she had not taken the advantage of ICT. She pays bills through mobile, make online shopping, and some other daily functions. She also mentioned that, if anyone wants, through use of ICT can make life easier and comfortable. She also opined that a positive change of mindset of both men and women might lead to such comfort.

Table 7. Overall access to ICT by women

\begin{tabular}{|l|l|l|l|l|l|l|l|l|}
\hline \multirow{2}{*}{ Access to ICT } & \multicolumn{2}{|l|}{ Barisal Sadar } & \multicolumn{2}{l|}{ South Manda } & \multicolumn{2}{l|}{ Char Sholakia } & \multicolumn{2}{l|}{ Total } \\
\cline { 2 - 9 } & No. & $\%$ & No. & $\%$ & No. & $\%$ & No. & $\%$ \\
\hline $\begin{array}{l}\text { High access to } \\
\text { ICT tools }\end{array}$ & 10 & 10 & 4 & 8 & 4 & 8 & 18 & 8.67 \\
\hline Moderate usage & 64 & 64 & 24 & 48 & 26 & 52 & 114 & 54.67 \\
\hline Low use of ICTs & 16 & 16 & 11 & 22 & 12 & 24 & 39 & 20.66 \\
\hline
\end{tabular}




\begin{tabular}{|l|l|l|l|l|l|l|l|l|}
\hline No use at all & 10 & 10 & 11 & 22 & 8 & 16 & 29 & 16 \\
\hline Total & 100 & 100 & 50 & 100 & 50 & 100 & 200 & 100 \\
\hline
\end{tabular}

Source: Based on respondent's opinion

From the above table, it is seen that on average only $8.67 \%$ of women highly use ICT tools. Most of the women use ICT tools irregularly and $20.66 \%$ of women use ICT hardly. $16 \%$ of women do not have control over ICT tools. Among 200 respondents in urban areas respectively $64 \%$ and $48 \%$ use ICT tools, in a rural area, $52 \%$ of women use ICT tools. Respondents were asked to choose a level of women's access to ICT.

Table 8. Gender constraints

\begin{tabular}{|l|l|l|l|l|l|l|l|l|}
\hline Constraints & \multicolumn{2}{|l|}{ Barisal Sadar } & \multicolumn{2}{l|}{ South Manda } & \multicolumn{2}{l|}{ Char Sholakia } & \multicolumn{2}{l|}{ Total } \\
\hline & No. & $\%$ & No. & \% & No. & \% & No. & \% \\
\hline Illiteracy & 13 & 13 & 6 & 12 & 5 & 10 & 24 & 11.67 \\
\hline $\begin{array}{l}\text { Access to ICT } \\
\text { tools }\end{array}$ & 30 & 30 & 15 & 30 & 10 & 20 & 55 & 26.67 \\
\hline $\begin{array}{l}\text { Economic } \\
\text { imbalances }\end{array}$ & 15 & 15 & 9 & 18 & 6 & 12 & 30 & 15 \\
\hline $\begin{array}{l}\text { Working } \\
\text { conditions }\end{array}$ & 25 & 25 & 7 & 14 & 5 & 10 & 37 & 16.33 \\
\hline $\begin{array}{l}\text { Remuneration } \\
\text { Social barriers }\end{array}$ & 7 & 7 & 8 & 16 & 12 & 24 & 27 & 15.67 \\
\hline $\begin{array}{l}\text { Control of } \\
\text { resources }\end{array}$ & 4 & 4 & 0 & 0 & 5 & 10 & 9 & 4.66 \\
\hline Total & 100 & 100 & 50 & 100 & 50 & 100 & 200 & 100 \\
\hline
\end{tabular}

Source: Prepared by the author

From the above data, it is identified $26.67 \%$ of the women do not have regular access to ICT tools. Especially in urban areas, women do not productively use ICT tools. In rural areas, $24 \%$ of respondents think that ICT usage is complicated and because of it, women get less value in a job. Some respondents think that technical work is only appropriate for men. Only $4.66 \%$ of women think that control of ICT resources is necessary. Reproductive roles are thought to be the primary responsibility of women. If the constraints factors are reduced, e-governance through proper access to ICT would be encouraged.

\section{CONCLUSION}

To achieve E-governance in Bangladesh enhancing women's access to ICTs is necessary. The productive usage of ICT can pave the way for women to be an equal stakeholders in the growing knowledge economy. The journey for establishing an e-governance system in Bangladesh faced challenges that can be summarized by three A's: Access, Awareness, and Applications. To promote women's full participation and involvement with ICTs, national and sector-wise policies need to support women's contribution to economic growth. Without the participation of both men and women, the growth and development of a country are quite impossible. Therefore, for ensuring governance and specifically E-governance in Bangladesh it is necessary to support women in ICT. The study unveils that ICT is that potentiality that can reach rural people and address their 
knowledge and information needs. It is found that there are area-specific constraints regarding women's access to devices and their utilization. Moreover, collecting data from women in rural areas was difficult. Measuring the increasing usage of ICT and its impact on E-governance needs a nationwide study. Though the study areas were different in the context of infrastructure and other development indicators, constraints were common. Women's access and control are yet to be addressed. That is why emphasis shall be given on the women's access to ICTs and proper usage of those which leads to a satisfactory level of E-Governance. Limitations of the study include lack of time, area, and more focus on social and economic impacts on achieving E-governance. Also, the security constraints should be addressed. Hence, further study would be necessary to reduce constraints and explore full potentialities.

\section{REFERENCES}

a2i. (2011). Strategic Priorities of Digital Bangladesh. Dhaka: Retrieved from www.a2i.pmo.gov.bd/tempdoc/strategic_priorities_of_Digital_Bangladesh_Jan_2011.pdf.

Akbar, M. S. U. (November 2018). Digital Bangladesh: Concepts of Development. AUEssays. Retrieved from https://www.auessays.com/essays/information-technology/digitalbangladesh-concept-of-development.php?vref=1

Ndou, V. (2004). E-Government for developing countries: opportunities and challenges. The electronic journal of information systems in developing countries, 18(1), 1-24. https://doi.org/10.1002/j.1681-4835.2004.tb00117.x

Salim, R. (2005). Cyber Security Bangladesh Perspectives. In ITU WSIS Thematic Meeting on Cyber Security, ITU Headquarters, Geneva, Switzerland June.

Tandon, N., Pritchard, S., Savelieva, V., Smith, R. G., \& Vogt, E. (2012). A bright future in ICT opportunities for a new generation of women. Geneva, Switzerland: International Telecommunication Union.

Taifur, S. A. S. M. (2006). SICT's Steps Towards Good Governance Through ICTs: E-governance Strategies. Center for Environmental and Geographic Information Services.

Zisan, T. H. (2014). A study on women's access to Information and communication technology. Barisal University Journal.

\section{Copyrights}

Copyright for this article is retained by the author(s), with first publication rights granted to the journal. This is an open-access article distributed under the terms and conditions of the Creative Commons Attribution license (http://creativecommons.org/licenses/by/4.0/) 